Jurnal Akuntansi dan Bisnis: Jurnal Program studi Akuntansi, 6 (1) Mei 2020.

ISSN 2443-3071 (Print) ISSN 2503-0337 (Online). DOI: 10.31289/jab.v6i1.2706

JURNAL AKUNTANSI DAN BISNIS

Jurnal Program Studi Akuntansi

Available online http://ojs.uma.ac.id/index.php/jurnalakundanbisnis

\title{
PENGARUH BOOK TAX DIFFERENCE TERHADAP RELEVANSI NILAI INFORMASI LABA
}

\author{
Pratana Puspa Midiastuty ${ }^{a^{*}}$, Eddy Suranta $^{a}$, Lidya Ofprama Dita ${ }^{a}$ \\ ${ }^{a}$ Fakultas Ekonomi dan Bisnis Universitas Bengkulu
}

Diterima Juli 2019, Disetujui November 2019, Dipublikasikan Mei 2020

\begin{abstract}
Abstrak
Penelitian ini bertujuan untuk menguji Book Tax Difference terhadap relevansi nilai informasi laba yang disajikan oleh perusahaan. Informasi relevansi nilai informasi laba diukur melalui nilai proksi ekuitas pasar. Penelitian ini mengklasifikasikan sampel perusahaan ke dalam kelompok ETR Tinggi dan kelompok ETR Rendah berdasarkan pada perhitungan tarif pajak efektif (ETR). Sampel penelitian ini adalah 85 perusahaan manufaktur yang terdaftar di Bursa Efek Indonesia pada tahun 2015-2018. Metode pengumpulan data, menggunakan teknik purposive sampling. Data pada penelitian ini dianalisis menggunakan ANOVA perbandingan T-Test untuk mengetahui apakah ada perbedaan antara perbedaan pembukuan pajak pada perusahaan yang termasuk ETR Tinggi dan ETR Rendah, dan analisis linear berganda menggunakan perangkat lunak SPSS untuk mengetahui apakah perusahaan dengan perbedaan pembukuan pajak buku besar dan termasuk kelompok ETR Rendah memiliki relevansi nilai informasi penghasilan rendah. Hasil penelitian menunjukkan bahwa terdapat perbedaan pendapatan buku dan pendapatan kena pajak pada agresif perusahaan (ETR Rendah) dan tidak agresif (ETR Tinggi). Perusahaan melakukan agresivitas pajak (ETR Rendah) memiliki nilai relevansi informasi yang lebih rendah daripada perusahaan tidak melakukan agresivitas pajak (ETR Tinggi).
\end{abstract}

Kata Kunci: Relevansi Nilai Informasi Penghasilan, Book Tax Difference, Tarif Pajak Efektif

\begin{abstract}
This research aims to test the book-tax difference towards the value relevance of earning information presented by the company. The value relevance of earning information in this study measured using market value equity proxy. This study classifies the sample of firms into a High ETR group and Low ETR groups based on the calculation of effective tax rate (ETR). The sample of this research is 85 manufacturing companies listed on the Indonesia stock exchange in 2015-2018. The Method of data collecting was using a purposive sampling technique. The data using ANOVA Test-Compare to find out whether there is a difference between the book-tax difference at companies that include High ETR and Low ETR, and multiple linear analysis using SPSS software find out whether companies with the large book-tax difference and included a group of Low ETR has the informational value relevance of earnings is low. The result showed that there is a difference in book income and taxable income on the company's aggressive (Low ETR) and not aggressive (High ETR). The company did the aggressiveness of the tax (Low ETR) has the value relevance of information lower than the company did not do tax aggressiveness (High ETR).
\end{abstract}

Keyword: Value Relevance of Earning Information, Book Tax Difference, Effective Tax Rate

How To Cite: Pratana Puspa Midiastuty, Eddy Suranta, Lidya Ofprama Dita (2020) Pengaruh Book Tax Difference Terhadap Relevansi Nilai Informasi Laba. Jurnal Akuntansi dan Bisnis: Jurnal Program Studi Akuntansi, 6 (1): 1-12 * email:pmidiastuty@yahoo.com

\section{PENDAHULUAN}

Laporan keuangan adalah catatan informasi keuangan suatu perusahaan pada suatu periode akuntansi yang dapat digunakan untuk menggambarkan kinerja perusahaan, dan diharapkan dapat berguna untuk memberikan informasi kepada semua pihak yang akan mempengaruhi pengambilan keputusan ekonomis yang rasional. Oleh 
karena itu, penyajian laporan keuangan harus memiliki nilai relevansi agar dapat berguna bagi pemakai laporan keuangan. Relevansi merupakan kemampuan informasi untuk membantu pemakai laporan keuangan dalam membedakan beberapa alternatif keputusan sehingga pemakai laporan keuangan dapat dengan mudah menentukan pilihan, membantu mengevaluasi masa lalu, masa sekarang, masa depan, dan menegaskan atau mengoreksi hasil evaluasi masa lalu (Suwardjono, 2008: 169).

Salah satu komponen laporan keuangan yang dijadikan sebagai alat penilaian kinerja perusahaan adalah laba. Menurut Barth et al., (2001) dan Scott (2009) perusahaan dapat dikatakan memiliki relevansi nilai laba yang baik jika informasi akuntansi tersebut dapat dijadikan dasar untuk memprediksi nilai pasar perusahaan, dengan kata lain relevansi laba dapat dikatakan baik jika nilai labanya dapat mempengaruhi harga saham perusahaan. Informasi laba juga dapat dijadikan dasar penentuan besarnya pengenaan pajak, yaitu informasi laba fiskal yang digunakan pihak pemerintah sebagai dasar pengenaan pajak perusahaan. Sehingga kandungan informasi laba akuntansi dan laba fiskal haruslah berkualitas karena akan digunakan bagi pihak berkepentingan dalam mengambil keputusan ekonomis.

Perbedaan laba menurut akuntansi dan laba menurut pajakatau disebut dengan book-tax differences (BTD) dapat terjadi karena adanya perbedaan antara Standar Akuntansi Keuangan (SAK) dan peraturan perpajakan. Dasar yang berbeda dalam penyusunan laporan keuangan tersebut dapat menimbulkan terjadinya perbedaan penghitungan laba (rugi) perusahaan yang menimbulkan istilah book-tax differences dalam analisis perpajakan (Resmi, 2011). BTD juga dapat disebabkan oleh adanya earning management yang dilakukan perusahaan, strategi perencanaan pajak (tax planning) perusahaan, dan perbedaan yang normal terjadi karena adanya perbedaan perlakuan atas pendapatan dan beban menurut akuntansi dan menurut pajak (Blaylocket al., 2012). Terdapat dua tipe BTD yaitu perbedaan yang sifatnya temporer dan perbedaan yang bersifat permanen. Perbedaan temporer terjadi karenaterdapatnya perbedaan waktu pengakuan penghasilan dan beban antara laporan keuangan fiskal dengan laporan keuangan komersial, dan perbedaan permanen yang terjadi karena terdapatnya peraturan yang berbeda antara Standar Akuntansi Keuangan dengan peraturan perundang-undangan perpajakan (Persada dan Martani , 2010).

Perencanaan pajak terdiri dari tindakan-tindakan yang bertujuan untuk merekayasa laba kena pajak perusahaan salah satunya adalah dengan melakukan tindakan pajak agresif. Menurut Frank et al.,(2009) tindakan pajak agresif merupakan suatu tindakan yang bertujuan untuk menurunkan laba kena pajak perusahaan melalui perencanaan pajak, baik menggunakan cara yang legal (tax avoidance) atau ilegal (tax evasion). Walaupun tidak semua tindakan yang dilakukan perusahaan melanggar peraturan perpajakan, namun semakin banyak celah yang digunakan untuk mengecilkan pajak maka semakin tinggi tingkat agresivitas perusahaan terhadap pajak. Perencanaan pajak yang dilakukan tidak hanya dapat memanipulasi laba fiskal tetapi juga dapat mempengaruhi laba akuntansi demi kepentinganperpajakan.Dengan merekayasa angka laba dalam laporan keuangan, kandungan informasi labayang dihasilkan dalam laporan keuangan perusahaan tersebut menjadi kurang informatif karena tidak lagi sesuai dengan kinerja perusahaan yang sebenarnya. Balakrishnan, et al., (2011) menyatakan bahwa perusahaan yang agresif terhadap pajak ditandai dengan transparansi yang lebih rendah karena terdapat kemungkinan manipulasi laba untuk kepentingan perpajakan. Pernyataan tersebut didukung oleh penelitian Desai dan Dharmapala (2006) yang menjelaskan bahwa, tindakan pajak agresif dalam aktifitas perencanaan pajak dapat terlihat dari adanya perbedaan BTD yang besar akan membuat menurunnya relevansi 
informasi laba yang dilaporkan perusahaan, karena memanfaatkan berbagai celah untuk menurunkan beban pajak yang dibayarkan oleh perusahaan.

Penelitian ini mengacu pada penelitian Noor dan Mastuki (2009) yang mengelompokkan sampel menjadi dua sub-sampel yaitu sampel Low ETR (perusahaan yang melakukan strategi Tax Aggressive) dan sampel High ETR (perusahaan yang tidak melakukan strategi Tax Aggressive). Relevansi laba diukur menggunakan price earning model yang diadaptasi dari penelitian Lev dan Nissim, 2002, 2004 dan Noor dan Mastuki, 2009. Penelitian ini diharapkan akan bermanfaat sebagai suatu benchmark atas perbedaan antara pendapatan sebelum pajak dalam laporan keuangan akuntansi dan laba kena pajak dalam laporan keuangan fiskal pada suatu perusahaan yang tergambar dalam book tax differences.

Perbedaan penelitian ini dengan penelitian sebelumnya terletak pada sampel penelitian. Pada penelitian sebelumnya sampel yang digunakan adalah seluruh perusahaan yang terdaftar di bursa Malaysia tahun 2000-2004 dan menggunaan dummy pada penentuan sampel, sedangkan penelitian ini menggunakan sampel perusahaan Manufaktur yang terdaftar di Bursa Efek Indonesia (BEI) tahun 2012-2015 dan tidak menggunakan dummy untuk penentuan sampel. BTD sebagai variabel independen serta relevansi nilai informasi laba sebagai variabel dependen. Adapun tujuan dan motivasi penelitian ini adalah belum banyak penelitian mengenai BTD yang dikaitkan dengan relevansi informasi laba, penelitian sebelumnya hanya mengaitkan BTDdengan persistensi laba. Fenomena perusahaan yang melakukan penghindaran pajak di Indonesia masih sering terjadi dan penelitian-penelitian sebelumnya masih menunjukkan hasil yang belum konsisten.

Rumusan masalah pada penelitian ini adalah apakah terdapat perbedaan antara laba akuntansi dan laba menurut perpajakan pada perusahaan yang agresif dan tidak agresif, apakah perusahaan yang mealkukan agresivitas pajak memiliki relevansi nlai informasi laba yang lebih rendah dari pada perusahaan yang tidak melakukan agresivitas pajak.Tujuan penelitian ini adalah untuk membuktikan terdapat perbedaan antara laba akuntansi dan laba menurut perpajakan pada perusahaan yang agresif dan tidak agresif, apakah perusahaan yang mealkukan agresivitas pajak memiliki relevansi nlai informasi laba yang lebih rendah dari pada perusahaan yang tidak melakukan agresivitas pajak.

BTD menjadi salah satu pengukuran yang dapat mencerminkan aktifitas penghindaran pajak yang dilakukan perusahaan terkait dengan adanya perbedaan tetap dan perbedaan sementara. Nilai BTD yang tinggi merefleksikan tindakan penghindaran pajak yang tinggi. Salah satu aktifitas penghindaran pajak yaitu tindakan pajak agresif. Pada umumnya, meskipun suatu perusahaan tidak melakukan tindakan untuk menghindari pajak, perbedaan antara laba akuntansi dan laba fiskal pasti terjadi, karena terdapat perbedaan pengakuan menurut SAK dan pihak perpajakan yang menyebabkan adanya BTD tersebut. Namun dalam penelitian ini ingin menguji apakah terdapat perbedaan nilai BTD pada perusahaan yang agresif dan perusahaan yang tidak agresif terhadap pajak. Untuk mengelompokkan perusahaan menjadi perusahaan yang agresif (Low ETR) dan tidak agresif (High ETR), penelitian ini menggunakan effective tax rate (ETR). ETR yang tinggi menunujukkan bahwa semakin rendah perusahaan melakukan penghindaran pajak yaitu jika nilai ETR > 25\% maka perusahaan tidak melakukan penghindaran pajak dan jika ETR $<25 \%$ maka perusahaan melakukan penghindaran pajak.

Beberapa penelitian sebelumnya telah mencoba berbagai macam proksi pengukuran penghindaran pajak, antara lain Effective Tax Rates (Noor dan Mastuki 2009; Chen et al., 2010; Sari dan Martani, 2010; Lanis dan Richardson, 2012, Beuselinck dan 
Deloof, 2006; Marginal Tax Rate (Gramlich et al., 2004; Beuselinck dan Deloof, 2014). Penelitian mengenai relevansi laba menggunakan pengukuran return saham(Lev dan Nissim, 2004; Hanlon et al., 2005; Chen et al., 2007; Ayers et al., 2009; Hamedian et al., 2014) dan Price Earnings Model (Lev dan Nissim, 2002, 2004 dan Noor dan Mastuki, 2009) sebagai indikatornya.

Perilaku menurunkan laba yang dilakukan oleh manajemen mengakibatkan biasinformasi kepada investor, perilaku tersebut tentunya akan mengurangi unsur penilaian investor terhadap perusahaan. Upaya manajemen dalam menurunkan beban pajak dapat berdampak pada harga saham perusahaan karena jika perusahaan telah memperkecil laba fiskal agar beban pajak yang dibayarkan menjadi kecil, berarti informasi yang diberikan oleh pihak manajemen tidak relevan yang dapat menurunkan nilai perusahaan terkait harga saham perusahaan tersebut. Perilaku untuk menurunkan beban pajak yang cenderung opurtunis memunculkan konflik keagenan. Konflik keagenan yang terjadi dari keputusan tindakan menurunkan beban pajak yangdilakukan oleh manajemen sehingga dikhawatirkan manajemen bersikap oportunis dengan melakukan tindakan penurunan beban pajak dengan memanfaatkan celah perbedaan Standar Akuntansi Keuangan (SAK) dan peraturan perpajakan tanpa memperhatikan keberlangsungan jangka panjang perusahaan seperti yangdiharapkan oleh pemegang saham. Manajemen perusahaan akan merencanakan pembayaran pajak yang relatif sedikit, dengan cara memanfaatkan kelemahan-kelemahan ketentuan perpajakan suatu negara.

\section{Teori Keagenan}

Jensen dan Meckling (1976) menyatakan yang dimaksud dengan principal adalah pemegang saham atau pemilik yang menyediakan fasilitas dan dana untuk kebutuhan operasi perusahaan. Agent adalah manajemen yang memiliki kewajiban untuk mengelola perusahaan sebagaimana yang telah diamanahkan principal kepadanya. Pemegang saham sebagai pemberi modal cenderung lebih berfokus pada laba yang akan didapatkan sebesar-besarnya atas hasil investasinya, sedangkan manajemen yang diberi wewenang untuk mengelola perusahaan menginginkan kompensasi keuangan yang tinggi dari perusahaan. Sehingga terdapat perbedaan tujuan antara pemegang saham dan pihak manajemen. Kepentingan yang berbeda antara manajemen dan pemilik tersebut dapat menimbulkan konflik yang secara eksplisit maupun implisit tercermin dalam laporan keuangan (Astika, 2010:65).

Perbedaan laba akuntansi dan laba fiskal (BTD), dimana besarnya nilai BTD yang merefleksikan perusahaan melakukan penghindaran pajak atau melakukan tindakan pajak agresif, hal ini berarti manajemen memiliki kepentingan untuk memanipulasi laba perusahaan, keputusan tindakan menurunkan beban pajak yangdilakukan oleh manajemen mengakibatkan biasinformasi kepada investor yang akan mengurangi unsur penilaian investor terhadap perusahaan, dan dikhawatirkan manajemenbersikap oportunis dengan melakukan tindakan penurunan beban pajak yang memanfaatkan celah perbedaan SAK dan peraturan perpajakantanpamemperhatikan keberlangsungan jangka panjang perusahaan seperti yang diharapkan oleh pemegang saham.

\section{Teori Akuntansi Positif}

Teori akuntansi positif (positive accounting theory-PAT) yang dipelopori oleh Watts dan Zimmerman (1986) menjelaskan bagaimana sebuah proses yang dilakukan dengan menggunakan pengetahuan serta memilih penggunaan kebijakan akuntansi yang paling tepat dan sesuai dengan kondisi tertentu yang terjadi saat ini atau dimasa mendatang. 
Dalam teori akuntansi positif ini terdapat prinsip yang beranggapan bahwa tujuan dari teori akuntansi adalah untuk menjelaskan dan memprediksi praktik-praktik akuntansi dengan pilihan-pilihan metode akuntansi yang diberikan dapat menjadi peluang bagi manajer untuk melakukan praktik manajemen laba dan perencanaan pajak, yang dapat menyebabkan laba yang dilaporkan tidak sesuai dengan yang sebenarnya sehingga rekayasa laba tersebut dapat mengurangi beban pajak.

Teori akuntansi positif mengusulkan tiga hipotesis motivasi manajemen laba yang dihubungkan oleh tindakan oportunistik yang dilakukan oleh perusahaan (Watts dan Zimmerman, 1986) yaitu hipotesis program bonus (the bonus plan hypotesis), hipotesis perjanjian utang (the debt covenant hypotesis) dan hipotesis biaya politik (the political cost hypotesis).Penelitian ini berhubungan dengan hipotesis biaya politik, yaitu semakin besar biaya politis yang dihadapi oleh perusahaan maka semakin besar pula kecenderungan perusahaan menggunakan pilihan akuntansi yang dapat mengurangi laba untuk meminimalkan biaya politik yang ditanggung. Rekayasa manipulasi laba yang dilakukan akan memungkinkan terjadinya penurunan laba yang dilaporkan sehingga pajak yang dibayarkannya menjadi kecil.

\section{Relevansi Nilai Informasi Laba}

Relevansi nilai merupakan konsep yang membahas tentang berbagai makna dan ukuran yang berkenaan dengan akuntansi (Puspitaningtyas, 2012). Menurut Suwardjono (2006, 2008) relevansi jika dikaitkan dengan tujuan pelaporan keuangan adalah kemampuan informasi untuk membantu investor, kreditur, dan pemakai lain dalam menyusun prediksi-prediksi tentang hasil dari kejadian masa lalu, sekarang dan masa datang serta informasi juga relevan dengan keputusan investasi.

Nursiah dan Nuryani (2014) menyebutkan bahwa relevansi nilai merupakan pelaporan angka-angka akuntansi yang memiliki suatu nilai prediksi berkaitan dengan nilai-nilai pasar ekuitas yang mencerminkan respon investor terhadap informasi akuntansi. Sehingga laporan keuangan akan menjadi relevan apabila kandungan informasi dalam laporan keuangan itu memiliki pengaruh dalam membuat keputusan investasi. Laba dan informasi yang dilaporkan secara benar didalam laporan keuangan juga dapat melihat nilai relevansi dari informasi tersebut.

Informasi laba yang disajikan dalam laporan keuangan perusahaan terbagi menjadi dua, yaitu laba akuntansi dan laba fiskal. Laba akuntansi didefinisikan sebagai salah satu indikator keberhasilan atau kegagalan suatu perusahaan dalam menjalankan aktivitasnya, sehingga informasi ini digunakan oleh investor dasar dalam pengambilan keputusan investasi. Dimana informasi tersebut digunakan perusahaan untuk menghitung laba fiskal perusahaan guna kepentingan perpajakan dengan melakukan rekonsiliasi fiskal. Informasi laba fiskal digunakan pihak pemerintah sebagai dasar pengenaan pajak perusahaan. PSAK No. 46 (2015) laba (rugi) fiskal merupakan laba (rugi) selama satu periode yang dihitung berdasarkan peraturan yang ditetapkan oleh otoritas perpajakan atas pajak penghasilan yang terutang (dipulihkan).

Menurut Syafutra (2016) semakin baik informasi yang disampaikan dari kedua komponen laba tersebut, maka semakin baik pula kandungan informasi laba yang dihasilkan dari suatu laporan keuangan perusahaan. Agar tidak menyesatkan dan merugikan para pengguna laporan keuangan, perusahaan dituntut untuk menghasilkan kandungan informasi laba yang baik dan relevan agar para penggunanya tidak salah dalam pengambilan keputusan. Pada penelitian yang dilakukan Lev dan Nissim (2002) dan Noor dan Mastuki (2009)menggunakan Price Earnings Model sebagai indikator untuk menilai harga pasar perusahaan. 
Manajemen laba dan perencanaan pajak dapat membuat informasi menjadi tidak relevan, karena dengan adanya manipulasi laba melalui tindakan manajemen laba dan penghindaran pajak akan menyebabkan terjadinya perbedaan antara laba menurut akuntansi dan laba yang dilaporkan pada pihak pemerintah. Perbedaan itulah yang disebut book tax difference. Semakin besar perbedaan antara laba akuntansi dan laba fiskal mengindikasikan terjadinya penghindaran pajak yang berarti informasi yang disajikan tersebut tidak relevan.

\section{Laba Akuntansi dan Laba Menurut Perpajakan pada Perusahaan yang Agresif dan yang Tidak} Agresif

Perbedaan kepentingan yang dimiliki antara manajemen dan investor menyebabkan adanya asimetri informasi. perbedaan kepentingan tersebut mendukung teori keagenan (Agency theory). Perbedaan laba akuntansi dan laba fiskal (BTD) dimana besarnya nilai BTD merefleksikan perusahaan melakukan penghindaran pajak atau melakukan tindakan pajak agresif, hal ini berarti manajemen memiliki kepentingan untuk memanipulasi laba perusahaan yang nantinya akan mengurangi utang pajak yang ditanggung oleh perusahaan. Keputusan tindakan menurunkan beban pajak yang dilakukan oleh manajemen dikhawatirkan manajemen bersikap oportunis dengan melakukan tindakan penurunan beban pajak dengan memanfaatkan celah perbedaan SAK dan peraturan perpajakan tanpa memperhatikan keberlangsungan jangka panjang perusahaan seperti yang diharapkan oleh pemegang saham. Manajemen perusahaan akan merencanakan pembayaran pajak yang relatif sedikit, dengan cara memanfaatkan kelemahan-kelemahan ketentuan perpajakan suatu negara.

Perusahaan yang melakukan perencanaan pajak yang salah satunya adalah tindakan pajak agresif, akan memiliki laba akuntansi dan laba fiskal yang berbeda dalam jumlah yang relatif besar (Hanlon et al., 2005), didukung oleh Noor dan Mastuki (2009) yang menjelaskan bahwa perusahaan yang agresif terhadap pajak cenderung memiliki nilai Book Tax Difference yang besar karena semakin banyak perusahaan memanfaatkan celah perbedaan SAK dan peraturan perpajakan makan perusahaan dinilai semakin agresif terhadap pajak.

H1 : Terdapat perbedaan laba akuntansi dan laba menurut perpajakan antara perusahaan yang agresif dan yang tidak agresif

\section{Perusahaan yang Agresif terhadap Relevansi Nilai Informasi Laba}

Hipotesis biaya politik menyatakan bahwa semakin besar biaya politis yang dihadapi oleh perusahaan maka semakin besar pula kecenderungan perusahaan menggunakan pilihan akuntansi yang dapat mengurangi laba untuk meminimalkan biaya politik yang ditanggung (Scott, 2009). Menurut teori keagenan perilaku memanipulasi laba yang dilakukan oleh manajemen, juga mengakibatkan biasinformasi kepada investor, perilaku tersebut tentunya akan mengurangi unsur penilaian investor terhadap perusahaan, karena informasi yang disediakan oleh pihak manajemen tidak sesuai dengan yang sebenarnya dan dapat dikatakan informasi tidak relevan. Upaya manajemen dalam menurunkan beban pajak dapat berdampak pada harga saham perusahaan karena jika perusahaan telah memperkecil laba fiskal agar beban pajak yang dibayarkan menjadi kecil, berarti informasi yang diberikan oleh pihak manajemen tidak sesuai dengan yang sebenarnya sehingga dapat menurunkan nilai perusahaan terkait harga saham perusahaan tersebut. 
Pada perusahaan yang memiliki agresivitas yang tinggi berarti perusahaan semakin banyak melakukaan tindakan penghindaran pajak oleh karena itu perusahaan tersebut memiliki relevansi nilai informasi laba yang rendah. Balakrishnan, et al., (2011) menyatakan bahwa perusahaan yang agresif terhadap pajak ditandai dengan transparansi yang lebih rendah karena terdapat kemungkinan manipulasi laba untuk kepentingan perpajakan. Pernyataan tersebut didukung oleh penelitian Desai dan Dharmapala (2006) yang menjelaskan bahwa, tindakan pajak agresif dalam aktifitas perencanaan pajak dapat terlihat dari adanya perbedaan book tax difference yang besar akan membuat menurunnya relevansi informasi laba yang dilaporkan perusahaan, karena pihak manajemen perusahaan memanfaatkan berbagai celah untuk menurunkan beban pajak yang dibayarkan oleh perusahaan.

Perusahaan yang memiliki nilai book tax difference yang tinggi maka perusahaan tersebut juga memiliki tingkat agresifitas yangtinggi dan akan membuat informasi laba semakin rendah karena adanya upaya menurunkan beban pajak perusahaan sehingga informasi tersebut semakin tidak relevan. Begitu pula pada perusahaan yang tingkat agresifitasnya rendah menandakan informasi laba yang disajikan relevan karena melaporkan laba yang sebenarnya dan tidak memanipulasi laba baik dengan manajemen laba atau perencanaan pajak.

H2 : Perusahaan Yang Melakukan Agresifitas Pajak Memiliki Relevansi Nilai Informasi Laba Yang Lebih Rendah dari pada Perusahaan Yang Tidak Melakukan Agresifitas Pajak

\section{METODE PENELITIAN}

\section{Data Penelitian}

Penelitian ini menggunakan data sekunder yaitu data laporan keuangan perusahaan yang terdaftar di Bursa Efek Indonesia (BEI). Teknik pengambilan sampling yang digunakan adalah secara non probability sampling yaitu purposive sampling. Sampel perusahaan yang diteliti adalah perusahaan yang selama periode pengamatan memenuhi persyaratan sebagai perusahaan manufaktur yang terdaftar di BEI periode 2015-2018, Perusahaan yang laporan keuangannya dalam mata uang rupiah, Mempunyai data yang lengkap untuk keseluruhan variabel, Perusahaan yang hanya menerbitkan satu jenis saham, Perusahaan yang tidak mengalami kerugian selama periode pengamatan.

\section{Populasi dan Sampel Penelitian}

Berdasarkan kriteria yang telah ditetapkan, maka jumlah sampel dalam penelitian ini berjumlah 85 perusahaan dengan periode penelitian selama 4 tahun.

\section{Variabel Penelitian, Definisi Operasonal dan Pengukuran Variabel \\ Variabel Dependen: Market value equity (MVE)}

MVE digunakan untuk merefleksikan relevansi nilai informasi laba mengacu pada penelitian Noor dan Mastuki (2009) yang menggunakan price earning model diadaptasi dari Lev and Nissim's (2002). Adapun rumus yang digunakan untuk mengukur relevansi nilai informasi laba yaitu :

$$
\text { MVE }=\frac{\text { Nilai Pasar Ekuitas }}{\text { Total Aset }}[1]
$$




\section{Variabel Independen: Book tax difference}

Book tax differenceyaitu perbedaan antara laba akuntansi dan laba fiskal dihitung menggunakan persamaan yang diadaptasi oleh Noor dan Mastuki (2009).

$$
\mathrm{BTD}=\frac{\text { Pre-tax income }- \text { Taxable Income }}{\text { Total Aset }}
$$

\section{Metode Analisis}

Metode analisis yang akan digunakan dalam penelitian ini meliputi statistic dekriptif, uji beda ANOVA-Compare means, dan uji hipotesis yang diolah dengan program Statistical Package For Social Science (SPSS) 22. Untuk uji beda digunakan uji ANOVA untuk menguji hipotesis 1 yakni apakah terdapat perbedaan antara laba akuntansi dan laba menurut perpajakan pada perusahaan yang agresif dan tidak agresif. Terakhir akan dilakukan pengujian analisis regresi linier berganda untuk menguji hipotesis 2dengan model regresi yang digunakan adalah:

Keterangan :

$$
M V E=\beta 0+\beta 1 B T D+\beta 2 E A R N S t+\beta 3 B V t+\beta t
$$

MVE : Nilai pasar ekuitas diskalakan dengan total asset

BV : Book value yang diskalakan dengan total asset

EARNS : Laba yang diskalakan dengan total Aset

BTD : Perbedaan laba akuntansi dan laba fiskal

\section{HASIL DAN PEMBAHASAN}

\section{Pengujian Hipotesis}

Hasil Pengujian Hipotesis 1

Tabel 1 di bawah ini menunjukkan hasil pengujian hipotesis one way ANOVAcompare means Low ETR dan High ETR

Tabel 1. Hasil pengujian hipotesis one way ANOVA-compare means Low ETR dan High ETR

\begin{tabular}{ccc} 
Variabel & F & Sig. \\
\hline BTD & 23.232 & 0.000 \\
EARNS & 11.617 & 0.001 \\
BVE & 14.095 & 0.000 \\
ETR & 12.061 & 0.001 \\
\hline
\end{tabular}

Berdasarkan Tabel 1 di atas, didapatkan hasil bahwa semua variabel bernilai signifikan yang berarti terdapat perbedaan antara laba akuntansi dan laba fiskal pada perusahaan yang telah dikelompokkan me jadi perusahaan agresif dan tidak agresif.Dari hasil yang didapatkan dapat disimpulkan hipotesis 1 diterima.Pengujian hipotesis 1 dengan menggunakan pengujian one way ANOVA-compare means menunjukkan bahwa terdapat perbedaan yang signifikan pada semua variabel antara High ETR dan Low ETR. Pada perusahaan yang termasuk agresif (Low ETR) perusahaan cenderung melaporkan laba fiskal yang lebih rendah dari laba akuntansinya. Perbedaan tersebut dapat dilakukan dengan memanfaatkan peraturan yang berbeda antara Standar Akuntansi Keuangan (SAK) dengan peraturan perpajakan, Selisih laba akuntansi dan laba fiskal tersebut karena terdapat perbedaan sementara (temporer) dan perbedaan tetap (permanen). Semakin besar selisih antara laba akuntansi dan laba fiskal 
mengindikasikan bahwa semakin besar kemungkinan perusahaan memanfaatkan beda tetap dan beda sementara untuk melakukan tindakan pajak agresif dan sebaliknya.

Penelitian ini sejalan dengan Noor dan Mastuki (2009) yang menemukan bahwa terdapat perbedaan antara laba akuntansi dan laba fiskal yang lebih besar pada perusahaan yang termasuk Low ETR atau perusahaan yang melakukan tindakan pajak agresif dari pada perusahaan yang termasuk High ETR atau perusahaan yang tidak melakukan tindakan pajak agresif.

Hasil Pengujian Hipotesis 2 dijabarkan dalam bentuk Tabel 2 Hasil Uji Analisis Regresi Linier Berganda

Tabel 2 Hasil Uji Analisis Regresi Linier Berganda

\begin{tabular}{cccc}
\hline & Full Sampel & High ETR & Low ETR \\
\hline Variabel & Koefisien & Koefisien & Koefisien \\
& $\mathrm{t}$ & $\mathrm{t}$ & $\mathrm{t}$ \\
& Sig & Sig & Sig \\
Konstanta & 0,061 & 0,445 & $-0,224$ \\
& 0,631 & 6,070 & $-1,156$ \\
BTD & 0,529 & 0,000 & 0,250 \\
& 3,358 & $-1,479$ & 8,120 \\
BVE & 2,320 & $-1,001$ & 3,369 \\
& 0,021 & 0,319 & 0,001 \\
& 1,237 & $-0,458$ & 0,992 \\
R Square & 4,697 & $-3,510$ & 2,838 \\
Adjusted R Square & 0,000 & 0,001 & 0,006 \\
F & 0,173 & 0,109 & 0,159 \\
Sig. & 0,165 & 0,093 & 0,142 \\
& 21,232 & 6,956 & 9,432 \\
\hline
\end{tabular}

Berdasarkan Tabel 2 di atas nilai F untuk sampel seluruh observasi sebesar 20,995 dan nilai signifikansi 0,000, karena nilai $F$ hitung $>F$ tabel $(21,232>3,890)$ dan signifikansi lebih kecil dari 0,05 maka model regresi untuk sampel seluruh observasi model yang digunakan fit. Sementara itu untuk sampel High ETR menunjukkan nilai F sebesar 6,956 dan nilai signifikansi 0,001, karena nilai F hitung > F tabel $(6,956>3,920)$ dan nilai signifikansi lebih kecil dari 0,05 maka model yang digunakan fit untuk sampel High ETR. Nilai F pada sampel Low ETR menunjukkan nilai sebesar 36.031dan nilai signifikansi F 0,001, karena nilai $F$ hitung > F tabel 9.432> 3,940) dan nilai signifikansi F lebih kecil dari 0,05 maka sampel Low ETR menunjukkan model yang baik (fit). Dengan demikian dapat disimpulkan bahwa model regresi pada penelitian ini memenuhi kriteria goodness of fit model.

Hasil pengujian pada tabel $4 \mathrm{di}$ atas, hasil regresi untuk pengujian hipotesis kedua didapatkan hasil bahwa nilai adjusted R square pada perusahaan High ETR sebesar 0,093 lebih rendah jika dibandingkan pada perusahaan Low ETR sebesar 0,142. Nilai adjusted $\mathrm{R}$ square yang lebih rendah pada kelompok High ETR daripada kelompok Low ETR dapat disimpulkan bahwa hipotesis 2 diterima. Sejalan dengan penelitian Noor dan Mastuki (2009) yang menemukan bahwa perusahaan yang termasuk Low ETR yaitu perusahaan yang di indikasi melakukan tindakan pajak agresif memiliki relevansi nilai informasi laba yang lebih rendah daripada perusahaan yang termasuk High ETR yaitu perusahaan yang tidak melakukan tindakan pajak agresif. Dengan melakukan berbagai metode untuk mendapatkan laba fiskal yang rendah sehingga beban pajak yang dikenakan juga rendah, 
hal tersebut dapat menurunkan relevansi dari informasi laba tersebut karena tidak lagi sesuai dengan keadaan perusahaan yang sebenarnya sehingga dapat menurunkan nilai perusahaan terkait harga saham perusahaan.

Balakrishnan, et. al. (2011) juga menyatakan bahwa perusahaan yang agresif terhadap pajak ditandai dengan transparansi yang lebih rendah karena terdapat kemungkinan manipulasi laba untuk kepentingan perpajakan. Pernyataan tersebut didukung oleh penelitian Desai dan Dharmapala (2006) yang menjelaskan bahwa, tindakan pajak agresif dalam aktifitas perencanaan pajak dapat terlihat dari adanya perbedaan book tax difference yang besar akan membuat menurunnya relevansi informasi laba yang dilaporkan perusahaan. Penelitian lainnya yang sejalan dengan hasil penelitian ini yaitu penelitian Hanlon (2005), Wijayanti (2006), serta Tang and Firth (2012) yang membuktikan bahwa nilai BTD yang besar menyebabkan relevansi nilai informasi laba yang rendah.

\section{SIMPULAN}

Hasil penelitian memberikan beberapa kesimpulan sebagai diantaranya terdapat perbedaan laba akuntansi dan laba menurut perpajakan pada perusahaan yang agresif (Low ETR) dan tidak agresif (High ETR) sehingga hipotesis pertama diterima. Kemudian perusahaan yang melakukan agresivitas pajak (Low ETR) memiliki relevansi nilai informasi laba yang lebih rendah dari pada perusahaan yang tidak melakukan agresivitas pajak (High ETR) yang terlihat dari nilai Adj.RSquare kelompok High ETR yang lebih rendah dari pada Adj.RSquare kelompok Low ETR sehingga hipotesis kedua diterima. Penelitian ini membuktikan bahwa terdapat perbedaan laba akuntansi dan laba menurut perpajakan (book tax difference) pada perusahaan yang agresif (Low ETR) dan tidak agresif (High ETR). Perbedaan ini terjadi dikarenakan adanya peraturan yang berbeda antara Standar Akuntansi Keuangan (SAK) dengan peraturan perpajakan. Bagi regulator dapat dijadikan tambahan referensi untuk membuat kebijakan baik dewan standar akuntansi maupun peraturan perpajakan mengenai gap antara laba akuntansi dan laba fiskal yang dapat mempengaruhi relevansi nilai informasi laba perusahaan serta praktik perencanaan pajak berdampak buruk bagi perekonomian. Bagi investor dapat dijadikan bahan pertimbangan dalam pengambilan sebuah keputusan terhadap perusahaan yang melakukan perencanaan pajak salah satunya melalui tindakan pajak agresif. Bagi akademisi dapat digunakan sebagai bahan acuan untuk penelitian berikutnya dengan topik yang sejenis yaitu pengaruh book tax differences terhadap relevansi nilai informasi laba perusahaan serta dapat dikembangkan untuk penelitian selanjutnya. Penelitian ini tidak terlepas dari keterbatasan-keterbatasan diantaranya adalah relevansi nilai informasi laba yang hanya diukur menggunakan Market Value Equitymemungkinkan informasi tersebut belum mampu menggambarkankeadaan pasar yang sebenarnya. Serta periode penelitian yang relatif pendek.

\section{DAFTAR PUSTAKA}

Astika, Putra., I.B. 2010. Teori Akuntansi: Konsep-Konsep Dasar AkuntansiKeuangan Denpasar Ayers, Benjamin C. Jiang, John X dan Laplante, Stacie K. 2009. Taxable Income asa Performance Measure: The Effects of Tax Planning and Earnings Quality. Contemporary Accounting Research, Vol. 26, No. 1, pp. 15-54.

Balakrishnan, Karthik, Blouin, Jennifer. Guay, Wayne. 2011. Does Tax Aggressiveness Reducee Financial Reporting Transparency. www.ssrn.com

Ball, Ray dan Brown, Philip. 1968. An Empirical Evaluation of Accounting Income Numbers.Journal of Accounting Research, Autumn, 1968. 
Barth, Mary E., Beaver, William H., dan Landsman, Wayne R. 2001. The Relevance of the Value Relevance Literature for Financial Accounting Standard Setting: Another View. Journal of Accounting and Economics, Vol. 31: 77-104.

Beuselinck dan Deloof M. 2006. Business Groups, Taxes, and Accrual Management. CentER Discussion Paper, Vol. 46. Tilburg University:Accounting.

Beuselinck, Cristoff dan Deloof Marc. 2014. Earnings Management in Business Groups: Tax Incentives or Expropriation Concealment? The International Journal of Accounting, Vol. 49, issue 1, pp. 27-52

Blaylock, B., Shevlin, T., dan Wilson, R. 2012.Tax avoidance, large positive book-tax-differences, and earning persistence.The Accounting Review, 87, 91-120.

Chen, Linda H. Dhaliwal, Dan S dan Trombley, Mark A. 2007.The Impact of Earnings Management and Tax Planning on the Information Content of Earnings. Working paper, Eller College of Management, University of Arizona, Tucson, Arizona.

Chen, S., Chen, X., Cheng, Q dan Shevlin, T. 2010. Are Family Firms More Tax Aggressive than Nonfamily Firms? Journal of Financial Economics, Vol. 95, hal. 41-61.

Cochrane, Donald dan Orcutt, Guy. 1949. Application of Least Squares Regression to Relationships Containing Auto-Correlated Error Terms. Journal of The AmericanStatistical Association, Vol. 44, No. 245, pp. 32-61.

Desai, M.A dan Dharmapala, D. 2006. Corporate Tax Avoidance and High Powered Incentives.Journal of Financial Economics, Vol. 79, hal. 145-179.

Dewan Standar Akuntansi Keuangan. 2015. PSAK No. 46 tentang Pajak Penghasilan

Dielman, Terry E. 1961. Applied Regression Analysis for Business and Economics. PWS-KENT Publishing Company.

Draft Pernyataan Standar Akuntansi Keuangan Nomor 1. Jakarta: Ikatan Akuntan Indonesia.

Frank, Mary Margaret. Lynch, Luann J and Rego, Sonja 0. 2009. Tax Reporting and ItsRelation to Aggressive Financial Reporting. Accounting Review, Vol. 84, No. 2, 2009.

Gramlich, J. D., Limpaphayom, P., \& Ghon Rhee. 2004. Taxes, Keiretsu Affiliation, and Income Shifting. Journal of Accounting and Economics, Vol. 37, no. 2, hal. 203-228.

Ghozali, Imam. 2011. Aplikasi Analisis Multivariate dengan Program SPSS.Semarang: Badan Penerbit Universitas Diponegoro.

Gujarati, Damodar. 2006. Dasar-Dasar Ekonometrika.Jakarta: Erlangga.

Hanlon, M. Maydew, Edward dan Shevlin, Terry. 2005. Book-tax conformity and the information content of earnings in a U.S. Setting. Working paper, University of Michigan, University of North Carolina and University of Washington.

Hamedian, Hamed. Rahdarian, Azar dan Kavyani, Mohsen. 2014. Information Content ofincome, Tax Avoidance and Taxable Income Management. Accountancy Business andthe Public Interest, 2014.

Jensen, Meckling. dan Meckling, W. 1976. Theory of The Firm: Managerial Behavior, AgencyCosts and Ownership Structure. Journal of FinancialEconomics, Vol. 3 No. 4, hal. 305-360.

Lanis, R. dan Richardson, G. 2012. The Effect of Board of Director on Corporate Tax Aggressiveness. Journal of Accounting and Public Policy. Vol. 30, hal.50-70.

Lev, B. dan Nissim, D. 2002.Taxable Income as an Indicator of Earnings Quality.Working Paper, New York University.

Lev, Baruch dan Nissim, Doron. 2004.The Accounting Review, Vol. 79, No. 4, pp. 1039-1074.

Martani, Dwi. 2009. Perbedaan Laba Akuntansi dan Laba Fiskal. Handbook Akuntansi Pajak Universitas Indonesia

Noor dan Mastuki 2009. Book Tax Difference and Value Relevance of Taxable Income. Journal of Financiaal Reporting and Accounting, Vol. 7, No 2, 19-40.

Nursiah dan N. Nuryani. 2014. Relevansi Nilai Serta Implikasi Risiko Atas Keuntungan dan Kerugian Perubahan Nilai Wajar Kewajiban Perbankan Indonesia. Simposium Nasional Akuntansi 17 Mataram, Lombok.

Persada, A.E dan Martani, D. 2010. Analisis Faktor yang Mempengaruhi Book Tax Gap dan Pengaruhnya Terhadap Persistensi Laba. Jurnal Akuntansi dan Keuangan Indonesia, 7(2), 205-221.

Puspitaningtyas.2012. Relevansi Nilai Informasi Akuntansi dan Manfaatnya bagi Investror. Jurnal Ekonomi dan Keuangan. ISSN 1411-0393.

Resmi, Siti. 2011. Perpajakan Teori dan Kasus Buku 1 Edisi 8. Jakarta: Salemba Empat.

Sari, Dewi Kartika dan Martani. 2010. Karakteristik Kepemilikan Perusahaan, Corporate Governance, dan Tindakan Pajak Agresif. Simposium NasionalAkuntansi XIII, Purwokerto.

Scott, William R. 2009. Financial Accounting Theory. Toronto: Pearson.

Suwardjono2008. Teori Akuntansi, Perekayasaan Pelaporan Keuangan. Yogyakarta: BPFE.V 
Pratana Puspa Midiastuty, Eddy Suranta, Lidya Ofprama Dita (2020) Pengaruh Book Tax Difference Terhadap Relevansi Nilai Informasi Laba...

Syafutra, E. 0.2016.Pengaruh Mnajemen Laba dan Perencanaan Pajak terhadap Kualitas InformasiLaba.Proceeding Universitas Tarumanegara.

Tang, T. Y., \& Firth, M. 2012. Earnings Persistence and Stock Market Reactions to the Different Information in Book-Tax Differences: Evidence from China. The International Journal of Accounting, 47, 369-397. From Iran". School of DoctoralStudies (European Union) Journal, Kurdistan, Iran.

Watts, Ross L and Zimmerman, Jerold L. 1990. Positive Accounting Theory: A Ten YearPerspective.American Accounting Association, Vol. 65, No.1, pp. 131-156

Wijayanti, Handayani Tri. (2006). Analisis pengaruh perbedaan antara laba akuntansi danLaba Fisal terhadap persistensi Laba, Akrual, dan Arus Kas. Simposium Nasional Akuntansi IX, Padang 